the incidence of psychiatric disorders. Again, her attention to design issues and measurement made for success.

Lee was in high demand to serve on national and international panels and task forces, including the World Health Organization expert panel on mental health. Deservedly, too, prestigious honours flowed in, including the Paul Hoch Award from the American Psychopathological Association in 1978, the Rema Lapouse Award from the American Public Health Association in 1979, the Sutherland Award from the American Society of Criminology in 1992, the Nathan B. Eddy Award from the College on Problems of Drug Dependence in 1993, and Honorary Fellowship of the Royal College of Psychiatrists in 1990. As this selection illustrates, her awards span a diverse range of areas.
Lee's first husband, Eli, died in 1994 after a long drawn-out neurological illness, and in 1998 she married Hugh Chaplin, a fellow faculty member. I saw them both soon after their marriage when they came to the UK and it was obvious how happy they were.

Lee is survived by Hugh and her four sons, Paul, Jamie, Tom and Nick, eight grandchildren and two great-grandchildren. Her scientific contributions will clearly live on but she will be remembered as much for the warmth and generosity of her personality. For me, as for many others, she was both a crucially important mentor and a much loved friend.

Michael Rutter doi: $10.1192 /$ pb.bp.110.029413

\section{Dr Brian Augustine O'Connell}

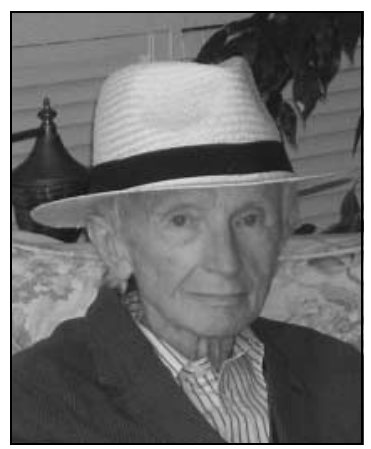

\section{Formerly Director, Northgate Clinic, London}

Brian O'Connell was born in Dublin on 8 November 1926 into a large Irish family whose paterfamilias, Timothy O'Connell, held a senior office in the Eire Department of Agriculture. Brian was educated at Belvedere College, described as 'an establishment run by the Jesuits for upper middle-class

Catholics'. For his medical training he attended University College Dublin, graduating MB, ChB, BAO in 1950.

Early on in his medical career, he decided to specialise in psychiatry, with emphasis on the forensic aspect. In pursuit of his aim, he took wing to Scotland and worked as a research registrar at the prestigious mental hospital, Crichton Royal, at Dumfries, for 4 years. He then headed south to London where he worked first at St George's Hospital, under the eminent Professor Desmond Curran, and then at the Maudsley, grabbing the offer to be seconded to Broadmoor Hospital, the UK's famous, or infamous, criminal lunatic asylum, where he gained a wealth of experience.

But his experience was crowned by his selection for a World Health Organization fellowship to the USA, where he had his pick from the rich variety of establishments devoted to forensic matters.

Returning to the UK with such an abundance of UK and US teaching under his belt, he could afford to wait for the most appropriate job to become available. And, in the event, he was allowed only a short time to twiddle his thumbs: a job came vacant which suited his talents and experience to a T. The job was vacant for medical director of the Northgate Clinic in north London which was succinctly described as 'an unconventional holistic and extremely successful centre with teenager mental health problems'. As is universally recognised, Brian was an undisputed success whose successor will be difficult to find.

Although his work so satisfactorily filled his day, he saw to it that at the end of the day he 'shut up shop'. For his private life, he sought a quite different milieu. His close friends were not medics, but littérateurs, journalists, artists and, in particular, those involved with the theatre. He loved discussion and argument - the more heated, the better - and, tell it not in Gath, he enjoyed a game of poker, accompanied, no doubt, with more than a modicum of the 'hard stuff'.

It is not surprising that, when he decided to marry, his choice for a wife was an actress, Fionnuala O'Shannon, whom he married in 1964. Tragically, she developed pancreatic cancer and died after what a friend described as a 'long and lively marriage'.

Brian himself, by a grim irony, also developed pancreatic cancer; he died on 18 September 2009.

So passed from the scene one of the most colourful characters of our time - a brilliant psychiatrist, scholar, raconteur and bon viveur. I can vouch for all these attributes. Years ago, I spent a delightful holiday with him in Crete, a country which gave him an opportunity to display his classical erudition. But he was never a bore, and when the occasion arose, he could charm the birds off the trees, metaphorically of course.

Henry R. Rollin

Photograph by Lelia Doolan

doi: 10.1192/pb.bp.110.029462 